\title{
Local seismic amplification analysis in the industrial area of Sulmona, Central Italy
}

\author{
A. Rinaldini, A. Grillo \& A. Marino \\ Department of Productive Activities and Interaction with the \\ Environment, ISPESL, Italy
}

\begin{abstract}
This paper deals with local seismic amplification analysis in the industrial district of the Sulmona basin (Central Italy) using both Nakamura's HVSR technique and 1-D numerical simulation computed with Shake91 code. An extensive geognostic database allows one to make out the geometries of the subsurface layers up to a depth of $50 \mathrm{~m}$ and cross-hole tests led to characterization of the dynamic proprieties of terrenes, namely the shear wave velocities values. Noise measurements were collected in the $0.1-10 \mathrm{~Hz}$ frequency domain and data were used to calibrate the 1-D simulations, performed using as source a seismic record of $\mathrm{M}=5.5$. The results obtained point out that local site effects are present in the central and eastern parts of the basin. Moreover, the comparison between the 1-D simulation spectra and the spectra of project provided in the Italian norms enhances the fact that in these areas the expected response is underestimated in the increased frequency range of buildings.

Keywords: geognostic investigations, dynamic properties, $H / V$ spectral ratios, resonance frequencies, 1-D simulation, industrial activities.
\end{abstract}

\section{Introduction}

Intramontane basins are a peculiar physiographic feature of the Apennine range in Central Italy. With flat extensions up to hundreds of $\mathrm{km}^{2}$, these endoreic structures of tectonic origin are characterized by a high seismicity and facilitate the development of important urban settlements and productive activities into the Apennine chain.

In this paper are presented the results of background noise measurements and 1-D simulations performed in the area of Sulmona. The main goal was to assess 
the local seismic response using different methodologies in an area where a potential seismic hazard exists caused by moderate-to-strong earthquakes originated in the Apennines.

\section{Geological setting}

The Sulmona basin is the easternmost of the great tectonic intramontane depressions that characterize the inner part of the Central Apennines. With a rectangular shape, the basin follows the patterns of the major tectonic structures active in the area $[1,2]$. The mountain ranges that delimit the plain are formed by calcareous successions deposited in different structural and paleo-geographical domains, fig.1; the basin is filled up with fluvial-lacustrine and continental deposits aged from Pliocene to Quaternary, with a thickness of about 500 meters.

\subsection{Structural geology}

The plain is delimited by Meso-Cenozoic limestone ridge-lines that since the late Miocene have been shortened, folded and thrust toward NE by a complex sequence of compressional phases (Parotto and Praturlon [3]). Post-orogenic extensions took origin during the late Pliocene, followed by a distensive tectonic that dissected the ancient fold-and-thrust structures and reactivated as normal faults many of the old surfaces of weakness, originating a half-graben structure deepening eastward.

The main structural feature is constituted by the Apennine trend fault system that delimits the plain in the N-E sector, active until the Holocene (Miccadei et al [2]).

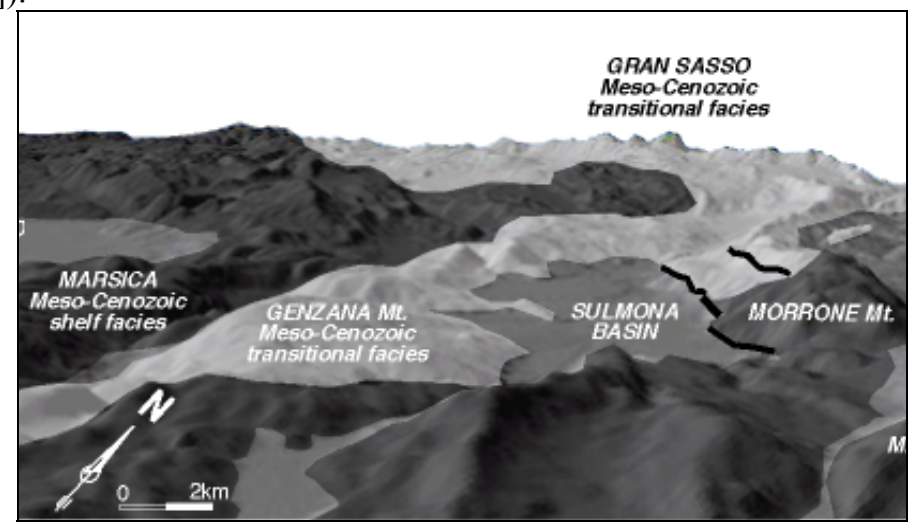

Figure 1: Three-dimensional model of the Sulmona basin surrounded by Mesozoic ridges of different paleogeographic origin.

\subsection{Seismicity}

The studied area is part of a highly seismic region of Central Italy and the available historic records are quite detailed $[4,5]$. Earthquakes with epicenters in 
the neighborhood of the town of Sulmona had a maximum intensity of VII MCS; yet Boschi et al [5] report that some major seismic events occurred on a regional scale, e.g. the 1706 Maiella (IX-X MCS) and the 1915 Fucino (VIII-IX MCS) earthquakes, shattering the area with loss of lives and wide building damage.

\section{Subsurface characterization of the Sulmona area}

The interpretation of the $\mathrm{H} / \mathrm{V}$ spectral ratios and transfer functions represents a fundamental task in the seismic characterization of a sediment site. To reach this goal, it is necessary the knowledge of thicknesses, geotechnical properties and shear-waves velocities of the subsurface layers.

A geotechnical characterization of the subsoil in the industrial district of Sulmona was thus accomplished, using a geognostic database that was developed both collecting new data from in situ prospectings, and acquiring informations provided by previous investigations.

\subsection{In-situ investigations}

The computing of the shear-waves velocities of subsurface layers was performed carrying out cross-hole $(\mathrm{C}-\mathrm{H})$ prospectings in 3 couples of boreholes located in and out the industrial district, fig. 2. Data from drillings were also used to integrate and validate the informations stored in the geognostic database.

Laboratory analyses on undisturbed core samples defined both the main static and dynamic geotechnical properties of the collected materials.

\subsubsection{Stratigraphies}

Two boreholes (S. Croce and La Torre) were drilled in continuous coring outside the industrial district, near the Mt. S. Cosimo ridge and reached depths of 58.5 and 54 meters respectively. In S. Croce site the lithologic succession is mainly constituted by thinly stratified silty-sands and silty-clays. In La Torre area the stratigraphy is formed by gravel layers interbedded with silty-clays and clays.

The sounding named Agricoltura was drilled in the eastern side of the industrial district, reaching a depth of 40 meters. Here the stratigraphic column is constituted by gravels that intercalate at various depths with silty-sands and siltyclays layers. Over-consolidated clays follow up to the bottom of the borehole.

\subsubsection{C-H investigations}

This prospecting has the advantage to investigate undisturbed materials and to operate on the rock mass scale. S-waves measurements were acquired using a three-directional geophone firmly fixed to the hole covering by means of a packer inflated with compressed air.

A hole hammer was the energizing source used. The hammer was lowered into one of the holes and fixed at the desired depth with extendable jaws controlled from outside. During data acquisition, step by step, source (S) and sensor $(\mathrm{G})$ were situated at the same height, allowing one to investigate the horizontal paths of shear waves, fig.3. 


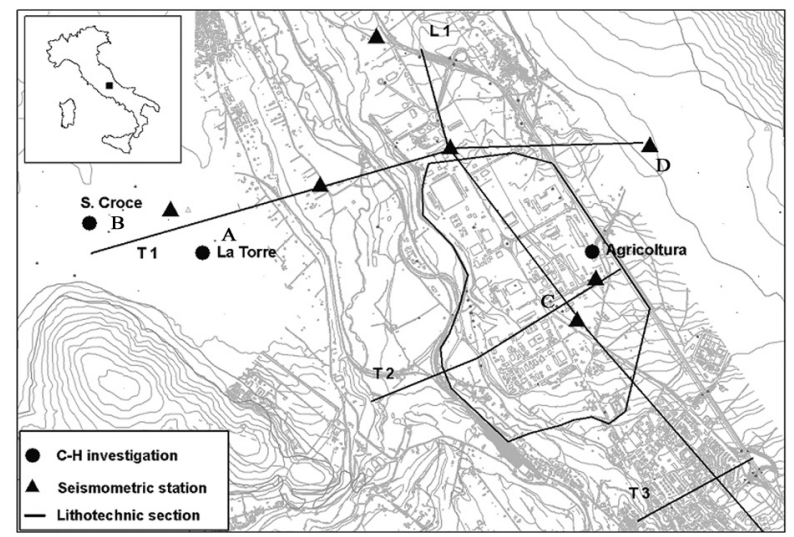

Figure 2: Location of in-situ prospectings carried out in the Sulmona industrial district. Both positions of lithotechnical cross-sections and synthetic stratigraphies are also shown.

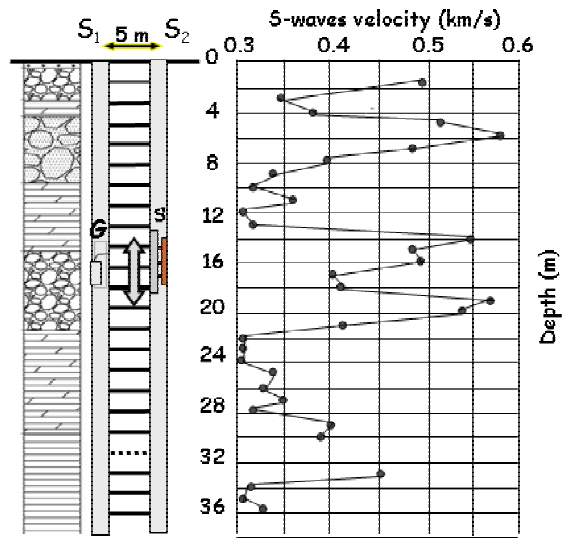

Figure 3: $\quad$ Shear waves velocity values measured in Agricoltura site.

3.1.2.1 Results Shear wave velocities measured in all the investigated sites show for gravels and coarse sands mean velocity values of about $450 \mathrm{~m} / \mathrm{s}$; for siltyclays and clays values range from 350 to $400 \mathrm{~m} / \mathrm{s}$.

\subsection{Geognostic database}

A detailed framework of the geometries and the physical-mechanical properties of buried layers was obtained using a geognostic database developed from 122 stratigraphic columns and 40 geognostic tests, half of them covering the industrial area. Many data were furnished by the geologist Mancini [6], others were collected during previous investigations (Rinaldini et al [7]). 
Soils with similar geotechnical proprieties were unified in homogeneous lithotechnical units and 4 cross-sections were drawn tracing the arrays of the seismometric measurements. This led to the reconstruction of the geometry of terrenes up to a depth $50 \mathrm{~m}$; the dataset provided also the quick identification, for each lithotechnical unit, of the main physical-mechanical properties affecting the seismic response.

\section{Background noise measurements}

A campaign of field investigations focused on the study of possible site effects was carried out around the industrial area of Sulmona. Background noise measurements were performed applying Nakamura's [8] technique, which is the ratio of the horizontal-component noise spectrum and that of the vertical component (HVSR).

Seismic arrays were set in the basin in continuous recording for the eventual acquisition of strong-motion data. As proposed in other studies [9-11] was placed in the site of Roccacasale a remote reference-site station, situated in the eastern edge of the basin. Yet nor weak nor strong motion data were recorded during the measurements.

\subsection{Field data}

During early March 2005 three arrays of noise measurements, each composed by 5 seismic stations, were performed in free-field disposed along the basin both longitudinally and transversally. Each seismic station was formed by a K2 seismometer, a GPS and three SS1 velocity sensors of $1 \mathrm{~Hz}$ frequency.

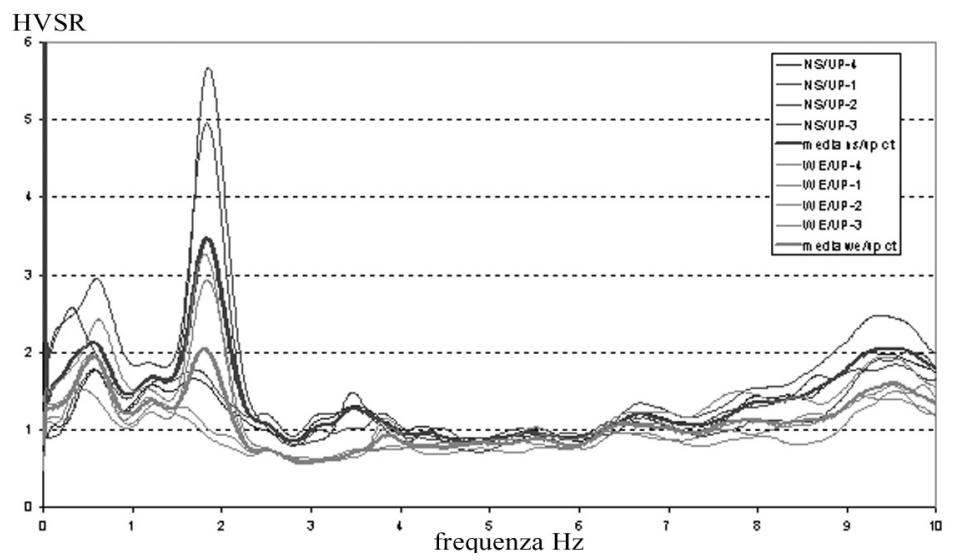

Figure 4: $\quad \mathrm{H} / \mathrm{V}$ spectral ratio measurements in Piano la Torre. Two peaks are reported, for each component, in the $0.6 \mathrm{~Hz}$ and $2 \mathrm{~Hz}$ frequency range. 
Background noise measurements were collected in the $0.1-10 \mathrm{~Hz}$ range, computing, for each component, the means of the Fourier spectra obtained in acquisition windows $40 \mathrm{sec}-$ long. The $\mathrm{H} / \mathrm{V}$ spectral ratios acquired during the day were compared and mediate for each component, fig. 4.

\subsection{Results}

HVSR analyses showed an amplification peak of about $0.6 \mathrm{~Hz}$ in all the stations located in the central sector of the basin, except for Park Hotel station where were not detected peaks under $3 \mathrm{~Hz}$. In the easternmost margin of the basin (Fonte Amore site) were not recorded peaks under $1 \mathrm{~Hz}$.

The spectral amplitudes measured on sediment sites are higher than that of the rock site. However, the Fourier spectra analysis showed that during the diurnal records, for all the stations and for each component, is present a sharp peak of $2 \mathrm{~Hz}$. The absence of such peaks during night times lead to suppose a human noise origin caused by traffic and industrial activities.

\section{1-D numerical simulation}

\subsection{Basics}

Along their paths towards the surface, shear waves modify their frequencies and amplitudes if pass from a speedy bedrock into a soft soil constituted by a succession of plain-parallel layers. This phenomenon originates site-effects on the ground that can be analyzed computing the ratio between the Fast Fourier spectrum (FFT) on the surface of the selected layer and that of the same component on the bedrock.

\subsection{Methodology}

The 1-D numerical simulations were aimed at analyzing the elastic behaviour of the ground under seismic shaking conditions. According to a linear-equivalent approach $[12,13]$, that generally fit with the geologic conditions present in the studied area, was used a mono-dimensional model and adopted the hypothesis of plain-parallel layers.

\subsubsection{Data input}

The amplification functions (AF) of the ground were obtained using the SHAKE-1D calculation code, applying 4 separate rules of decay $\mathrm{G} / \mathrm{G}_{0}$ and a dumping factor of $5 \%$ in the hypothesis of PGA values equal to $0.09 \mathrm{~g}$. These PGA values were also used to elaborate the spectra of project proposed in the Italian Technical Norms for the Constructions [14].

All numerical simulations obtained were calibrated on the results of the $H / V$ spectral ratio measurements.

5.2.1.1Geologic information The geognostic database allowed to make out 5 synthetic stratigraphic columns, namely La Torre (A), S. Brigida, Hotel S. Croce 
and La Vigna (B), Park Hotel (C), Fonte Amore (D) and Raiano (E) on the sites where were located the HVSR stations. Each layer of the stratigraphic columns was thus characterized in terms of the dynamic properties, as shown in table 1.

5.2.1.2 Strong motion source The Raiano seismic station was used as bedrock and the input parameter for the strong motion simulation was the record of the 1984 S. Donato Valcomino earthquake $(M=5.5)$, measured in the Atina station (FR), that belongs to the National Accelerometric Network (NAN).

Table 1: $\quad$ Dataset showing the main dynamic characteristics of site B.

\begin{tabular}{|c|c|c|c|c|c|c|c|}
\hline \multicolumn{7}{|c|}{ B stratigraphy (S. Brigida, Hotel S. Croce, La Vigna) } \\
\hline layer & lithology & S-waves & density & height & depth & $\mathrm{D}$ & $\mathrm{G}_{/} \mathrm{G}_{0}$ \\
\hline & & $\mathrm{m} / \mathrm{s}$ & $\mathrm{t} / \mathrm{m}^{3}$ & $\mathrm{~m}$ & $\mathrm{~m}$ & $\%$ & \\
\hline I & silt & 350 & 1.90 & 1.5 & & 5 & 2 \\
\hline II & gravel & 450 & 1.80 & 11 & 12.5 & 5 & 1 \\
\hline III & silty-clay & 350 & 1.90 & 12 & 24.5 & 5 & 3 \\
\hline IV & gravel & 450 & 1.80 & 4.5 & 29 & 5 & 1 \\
\hline V & silty-clay & 350 & 2.00 & 18 & 47 & 5 & 3 \\
\hline VI & silt & 400 & 2.10 & 103 & 150 & 5 & 3 \\
\hline bedrock & limestone & 1000 & 2.40 & & & 1 & \\
\hline
\end{tabular}

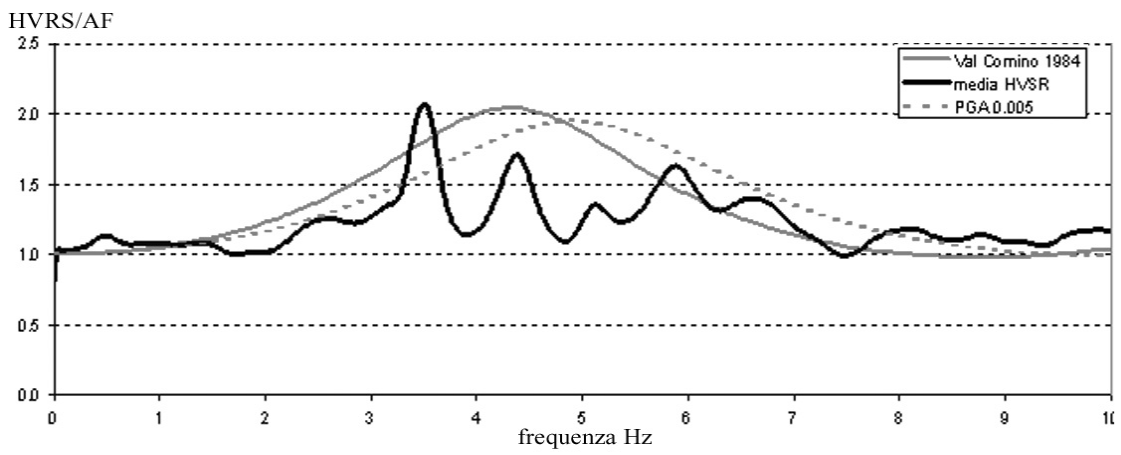

Figure 5: Diagram showing the $\mathrm{H} / \mathrm{V}$ spectral ratio and the AF values in Park Hotel site.

\subsection{Data output}

The amplifying functions obtained from the strong motion simulation enhance the presence of frequencies peaks in the $0.6 \mathrm{~Hz}$ and the $2 \mathrm{~Hz}$ range. These values are respectively referable to the thickness of the deposits and to the second vibration mode of the ground. The amplification factor for such frequencies is respectively about 2.5 and 1.8. These results are quite similar in all the investigated sites, except for the Park Hotel stratigraphy. 


\subsubsection{Park Hotel site}

The amplifying function enhances a resonance value included in a frequency range from $3 \mathrm{~Hz}$ to $5 \mathrm{~Hz}$, probably caused by the local stratigraphy. In fact, the 1-D simulation and the HVSR data indicate the lack of a sharp rigidity contrast between the sedimentary cover and the seismic bedrock, constituted in this site by flysh. The correspondent value of the amplification factor is about 2 , fig 5 .

\subsection{AF spectral analyses}

The AF spectra obtained from the 1-D simulation were compared with the spectra of project proposed in Technical Norms for the Constructions, and for each stratigraphy was adopted the related soil-type, as shown in table 2 .

Table 2: $\quad$ Parameters of the Technical Norms and related stratigraphies.

\begin{tabular}{|c|c|c|c|c|c|c|c|c|}
\hline Sites & Soil & $\mathrm{V}_{\mathrm{S} 30}(\mathrm{~m} / \mathrm{s})$ & $\mathrm{S}$ & $\mathrm{T}_{\mathrm{B}}$ & $\mathrm{T}_{\mathrm{C}}$ & $\mathrm{T}_{\mathrm{D}}$ & $\xi \%$ & $\mathrm{a}_{\mathrm{g}}$ \\
\hline $\mathrm{A}$ & $\mathrm{C}$ & 411 & 1.25 & 0.15 & 0.50 & 2.00 & 5 & 0.35 \\
\hline $\mathrm{B}$ & $\mathrm{C}$ & 411 & 1.25 & 0.15 & 0.50 & 2.00 & 5 & 0.35 \\
\hline $\mathrm{C}$ & $\mathrm{C}$ & 455 & 1.25 & 0.15 & 0.50 & 2.00 & 5 & 0.35 \\
\hline $\mathrm{D}$ & $\mathrm{E}$ & 452 & 1.25 & 0.15 & 0.50 & 2.00 & 5 & 0.35 \\
\hline $\mathrm{E}$ & $\mathrm{C}$ & 400 & 1.25 & 0.15 & 0.50 & 2.00 & 5 & 0.35 \\
\hline
\end{tabular}
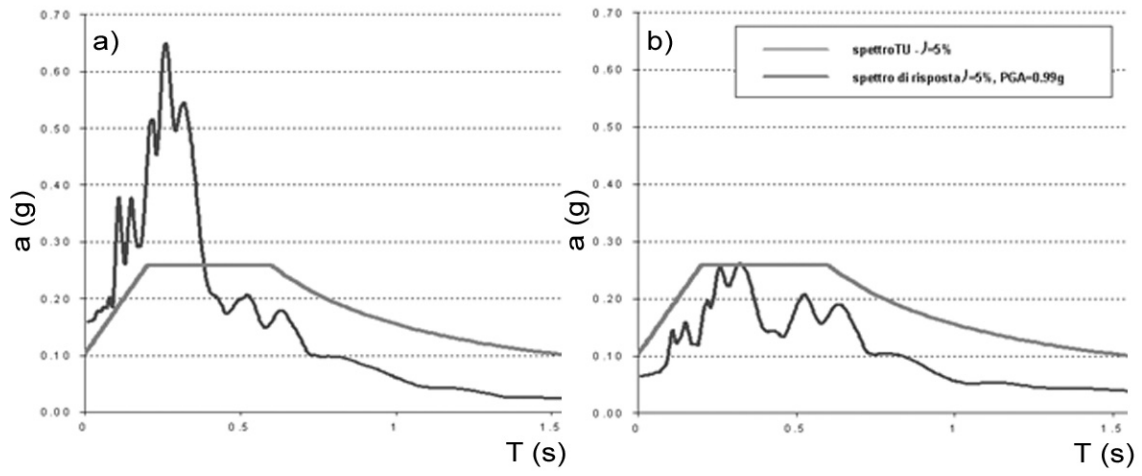

Figure 6: Comparison between the obtained 1-D spectrum of response and the elastic spectrum of project in: a) Fonte Amore, b) Raiano.

In the $\mathrm{A}, \mathrm{B}$ and $\mathrm{E}$ sites the obtained $\mathrm{AF}$ fits with the spectrum of project; otherwise, in $\mathrm{C}$ and $\mathrm{D}$ the spectra obtained in the 1-D simulation are higher than the spectra of project for periods of $0.3-0.4 \mathrm{~s}$, as shown in figures $6 \mathrm{a}$ ) and $6 \mathrm{~b}$ ). The $\mathrm{C}$ and $\mathrm{D}$ stratigraphies are respectively related to a seismic substratum that lacks in a high rigidity contrast, and to an area where the thickness of soft soils reaches the maximum depth. 


\section{Conclusions}

This study deals with the assessment of the local seismic response in the Sulmona basin, applying two different methodologies. In the former, based on the HVSR technique, results showed amplification peaks of about $0.6 \mathrm{~Hz}$ in the stations located in central sector of the basin, except for Park Hotel site. A $2 \mathrm{~Hz}$ peak was also measured in all the seismometric stations during the diurnal records, probably due to anthropic factors.

The latter technique consisted in a numerical simulation performed under strong motion conditions, using the SHAKE 91 software. As input parameters were used the dynamic proprieties of soils and the seismic source was the 1984 S. Donato Valcomino earthquake $(M=5.5)$, measured in the NAN station of Atina. The amplification functions of the ground, obtained with SHAKE-1D, were calibrated with the HVSR investigations data.

The 1-D simulation results, compared with the spectra of project provided in the actual Italian norms, enhanced the fact that the expected response, in the interested frequency range of buildings, is underestimated for the stations of Park Hotel and Fonte Amore. These are located respectively in the central sector of the plain, where the seismic substratum lacks a high rigidity contrast, and in the eastern margin of the basin where the lithologic succession reaches the maximum thickness.

\section{References}

[1] Ciccacci, S., D'Alessandro, L., Dramis, F. \& Miccadei, E., Geomorphological evolution and neotectonics of the Sulmona intramontane basin (Abruzzi, Apennine, Central Italy). Zeitscschift fur Geomorphologie, 118, pp. 27-40, 1999.

[2] Miccadei E., Paron, P \& Piacentini T., The SW escarpment of the Montagna del Morrone (Abruzzi, Central Italy): geomorphology of a faulted-generated mountain front. Geogreafia Fisica e Dinamica Quarternaria, 27(1), pp. 55-87, 2004.

[3] Parlotto, M. \& Praturlon A., Geological summary of central Apennines (Chapter 3). Structural Model of Italy, ed. C.N.R., Roma, pp. 257-311.

[4] Postpischil, D., Catalogo dei terremoti italiani dall'anno 1000 al 1980. Quaderni della Ricerca Scientifica, 114(2B), pp. 239, 1985.

[5] Boschi, E., Ferrari, G., Gasperini, P., Guidoboni, E., Smriglio, G. \& Valensise G., Catalogo dei forti terremoti in Italia dal 461 a.C. al 1980, ING-SGA: Bologna, pp. 543-549, 1995.

[6] Mancini, A., Personal communication, 19 April 2006, Consortium for the Sulmona industrial development, Sulmona, Italy.

[7] Rinaldini, A., Pecci, M., Marino, A., Bellagamba, S. \& Ciucci, M., Sviluppo di un database geologico per l'analisi dei rischi naturali nelle attività della Piana di Sulmona (L'Aquila). Atti Quarto Convegno valutazione e gestione del rischio negli insediamenti civili e industriali, Pisa,110.pdf, 2004. 
[8] Nakamura, Y., A method for dynamic characteristics estimation of subsurface using microtremors on the ground surface. Quarterly Reports of the Railway Technical Research Institute Tokyo, 30, pp. 25-33, 1989.

[9] Borcherdt, R.D., Estimates for site response spectra for design (methodology and justification). Earthquake spectra, 10, pp. 617-653, 1994.

[10] Lachet, C., Bouchon, M., Theodulidis, N. \& Bard, P.Y., Horizontal to vertical spectral ratio and geological conditions. Proc. of the X Europ. Conf. On Earthquake Engineering, Balkema: Rotterdam, pp. 285-289, 1995.

[11] Bard, P.Y., Effects of surface geology on ground motion: recent results and remaining issues. Proc. of the X Europ. Conf. On Earthquake Engineering, Balkema: Rotterdam, pp. 305-323, 1995.

[12] Schnabel, P.B., Lysmer, J. \& Seed, H.B., Shake a computer program for earthquake response analysis of horizontally layered sites. User's manual, Earthquake engineering research center, University of California: Berkley, 1972.

[13] Idriss, J. \& Sun, J.I., SHAKE91- A computer program for conducting equivalent linear seismic response analysis of horizontally layered soil deposits. Dep. Of Civil and Environmental Engineering, University of California: Davis, 1992.

[14] Gazzetta Ufficiale della Repubblica Italiana (eds). Norme Tecniche per le Costruzioni, Testo Unitario, n. 222 del 23/9/2005 